Jurnal Evaluasi dan Pembelajaran

Volume 3 Nomor 1, Tahun 2021

Available online at https://jepjurnal.stkipalitb.ac.id/index.php/hepi

\title{
IMPLEMENTASI NILAI PANCASILA TERHADAP ESENSI NILAI HUMANISME DALAM KEHIDUPAN BERMASYARAKAT DI KALANGAN GENERASI MUDA
}

\author{
Awalia Marwah Suhandi ${ }^{*}$, Dini Angraeni Dewi ${ }^{1}$ \\ 1Universitas Pendidikan Indonesia Kampus Daerah Cibiru \\ Jalan Pendidikan Nomer 15, Bandung, Jawa Barat 40625. \\ *Corresponding Author: awaliamarwah@upi.edu
}

\begin{abstract}
Abstrak
Nilai humanisme pancasila merupakan aspek yang sangat penting bagi kepribadian yang saling menghargai dan menghormati pada kalangan generasi muda. Nilai humanisme harus dimaknai sebagai upaya pencegahan dan pencapaian kehidupan yang rukun, nyaman, dan sentosa. Nilai kemanusian dalam kehidupan bermasyarakat dinilai ketika masyarakat itu mampu menghargai dan menghormati hak dan kewajiban yang dimiliki orang lain dalam berkehidupan berbangsa dan bernegara. Hasil penelitian dengan mengkaji pemikiran Budi Hardiamansyah adalah nilai humanisme yang luntur dikalangan generasi muda harus terus ditingkatkan karena nilai humanisme ini sudah perlahan luntur dikalangan masyarakat khususnya kalangan generasi muda. Dalam hal ini penerapan nilai humanisme dalam pancasila sangat asing bagi mereka yang menganggap bahwa nilai kemanusiaan tidak penting di terapkan di kehidupannya karena sudah terbalut rasa egois dalam berkehidupan di lingkungan masyarakat. Tujuan penelitian berbasis kajian teori ini berguna untuk memaknai nilai humanisme dalam kehidupan bermasyarakat di kalangan generasi muda. Metode analisis yang digunakan yaitu studi literature dengan pendekatan kualitatif. Kesimpulan dari penelitian dengan kajian literature ini adalah generasi muda merupakan tolak ukur kemajuan suatu bangsa dengan menjiwai dan mengamalkan nilai pancasila khususnya nilai kemanusiaan maka akan menghantarkan kepada sebuah jalan menuju puncak kebahagiaan kehidpuan di dunia yaitu sikap menghargai dan toleransi di dalam kehidupan bermasyarakat.
\end{abstract}

Kata Kunci: Generasi muda, Nilai Humanisme, Pancasila

\begin{abstract}
The value of Pancasila humanism is a very important aspect of a personality that respects and respects the younger generation. Value of humanism must be interpreted as an effort to prevent and achieve a harmonious, comfortable and safe life. The value of humanity in social life is assessed when the community is able to respect and respect the rights and obligations of others in the life of the nation and state. The result of research by examining Budi Hardiamansyah's thoughts is that the fading value of humanism among the younger generation must continue to be improved because the value of humanism has slowly faded among the community, especially among the younger generation. In this case, the application of the value of humanism in Pancasila is very foreign to those who think that human values are not important to be applied in their lives because they are already wrapped in a sense of selfishness in living in the community. The purpose of this theoretical study-based research is useful for interpreting the value of humanism in social life among
\end{abstract}




\section{Jurnal Evaluasi dan Pembelajaran, 3 (1), Maret 2021 - 37}

Awalia Marwah Suhandi, Dinie Angraeni Dewi

the younger generation. The analytical method used is literature study with a qualitative approach. The conclusion of this research with literature review is that the younger generation is a measure of the progress of a nation by living and practicing the values of Pancasila, especially human values, which will lead to a path to the peak of happiness in the world, namely the attitude of respect and tolerance in social life.

Keywords : Young Generation, Value of Humanism, Pancasila

\section{Pendahuluan}

Nilai pancasila merupakan sebuah sumber nilai, baik nilai dasar dan nilai abadi. Hal ini sejalan dengan pendapat Rianto (2016) yang menyatakan Pancasila sebagai ideologi negara merupakan wujud penjelmaan nilai-nilai kearifan lokal masyarakat Indonesia secara menyeluruh, oleh karena itu nilai- nilai yang ada itu perlu dipahami dan diamalkan oleh semua warga negara, mengerti dan menyadari bahwa Pancasila sebagai sumber nilai, baik nilai dasar yang bersifat abadi dalam Pembukaan UUD 1945, nilai instrumentalnya, maupun nilai praksisnya dalam kehidupan sehari-hari yang nyata dilaksanakan oleh masyarakat luas.

Nilai-nilai dari sila-sila Pancasila mengamanatkan kepada warga negara Indonesia untuk selalu mengingat semangat religi, memuliakan martabat manusia, kesatuan dan persatuan bangsa, demokrasi, serta keadilan sosial dalam kehidupan bermasyarakat, berbangsa, dan bernegara, dalam wujud yang selalu tumbuh dan berkembang semakin baik. Hal ini sejalan dengan pendapat Arif (2016) adanya nilai pancasila dalam kehidupan berbangsa dan bernegara harus di ambil sisi positifnya misalnya adalah demokrasi dan hidup rukun kepada sesama.

Hal ini menunjukan bahwa dalam penerapan sila-silanya memiliki esensi dan ciri khas masing-masing sila tersebut. Penerapan nilai kemanusiaan di dalam sila pancasila bisa diterapkan berdasarkan pendidikan humanisme pancasila dengan beberapa gambaran atau bayangan. Adapun, menurut Mustohfa (2017) menyatakan karakteristik pendidikan humanisme pancasila adalah dengan menghormati keyakinan religius, menghormati martabat hak asasinya, memiliki wawasan kebangsaan, menghargai kebebasan secara demokratis, dan menunjunjung dan menegakkan keadilan sosial.

Pancasila merupakan cerminan dan tujuan bangsa Indonesia untuk meraih kesejahteraan. Hal ini sejalan dengan pendapat Airlam (2018) yang mengatakan bahwa nilai pancasila telah membimbing suatu kehidupan bangsa menjadi lebih baik dengan suatu tujuan yang relavansinya jelas, terarah, dan terukur. Dalam hal ini, artinya semua nilai yang terkandung dalam Pancasila memiliki tujuan dan diterapkan sesuai kondisi bangsa Indonesia.

Semua hal yang berkaitan dengan kehidupan berbangsa dan bernegara pasti terikat dengan nilai pancasila. Nilai pancasila yang mencangkup nilai ketuhanan, kemanusiaan, persatuan, kerakyatan, dan keadilan merupakan nilai yang ada di dalam jati diri bangsa indonesia dan merupakan suatu pedoman berbangsa dan bernegara. Nilai ketuhanan diletakan di sila pertama karena, sepandai atau sepintar apapun orang tersebut, maka sebagai makhluk ciptaannya harus senantiasa ingat kepada tuhan yang maha esa. selanjutnya terdapat nilai persatuan, kerakyatan, dan keadilan.

Dalam hal ini, nilai tersebut dijadikan suatu arah bagi bangsa, dengan menyikapi realitas kehidupan berbangsa dan bernegara. Misalnya nilai persatuan, maka sebagai bangsa yang terdiri dari sabang sampai merauke harus memberikan kontribusi suatu persatuan kepada negara Indonesia. Namun nilai yang tidak kalah penting dibandingkan nilai lainnya adalah nilai kemanusiaan. Nilai ini ditempatkan di sila kedua dengan berbagai pertimbangan, karena sejatinya nilai kemanusiaan penting bagi suatu bangsa. Dengan nilai 
kemanusiaan seseorang tidak akan melupakan kewajiban sebagai warga negara dan tidak akan melanggar hak-hak yang dimiliki orang lain. Sikap memanusiakan manusia dalam nilai kemanusiaan merupakan suatu gambaran bahwa nilai kemanusiaan dalam pancasila urgensinya sangat penting.

Pada zaman sekarang, banyak sekali fenomena permasalahan kemanusiaan di lingkungan berbangsa dan bernegara. Permasalahan ini tidak memandang usia, dari dewasa bahkan generasi muda turut menjadi sorotan permasalahan fenomena kemanusiaan. Fenomena tersebut misalnya, tidak saling menghargai, tidak ada sikap toleransi, Bodyshaming di kalangan generasi muda, rasisme yang melanda, dan tidak menghargai pendapat. Hal ini, jika dibiarkan terus berlangsung akan mengakibatkan sebuah krisis kemanusiaan. Karena sejatinya manusia ingin dihargai dan dihormati, namun terkadang lupa bahwa ada orang lain disekitarnya yang harus dihormati dan dihargai juga.

Cara dan upaya yang paling efektif adalah dengan mengamalkan dan menjiwai nilainilai pancasila di dalam diri masing-masing warga negara. apabila sudah menerapkan nilai pancasila tersebut di dalam diri, maka hidup akan berlangsung secara damai di semua kalangan, baik dewasa maupun dikalangan generasi muda.

Dengan adanya permasalahan kemanusiaan tersebut, suatu rumusan permasalahan mengenai bagaimana suatu nilai pancasila hadir menjadi solusi atau upaya krisis kemanusiaan di kalangan generasi muda dengan semua fenomena permasalahan dan esensi nilai humanisme yang terkandung dalam nilai kemanusiaan dapat diimplementasikan dalam kehidupan berbangsa dan bernegara.

Humanisme dalam pancasila bisa menjadi petujuk atau cara bagaimana seseorang dapat bertindak sesuai nilai humanis dalam pancasila. Kemanusiaan di kehidupan bermasyarakat urgensinya sangat penting dan harus dijunjung tinggi. Nilai kemanusiaan harus diciptakan dikehidupan bermasyarakatan karena dengan terciptanya nilai kemanusiaan, maka akan terbentuknya suatu nilai kebaikan di lingkungan masyarakat khususnya dilingkungan generasi muda saat ini yang sering terjadi krisis kemanusiaan. Menurut Evie (2014) mengatakan bahwa nilai kemanusiaan terdiri dari nilai kebenaran, kebijakan, kedamaian, kasih sayang, dan tanpa kekerasan. Hal ini menandakan bahwa generasi muda harus memiliki nilai kemanusiaan sesuai nilai sila kemanusiaan untuk diaplikasikan di kehidupannya.

Generasi muda memegang peranan penting dalam pembentukan suatu bangsa. Kesadaran mengenai fenomena permasalahan kemanusiaan harus dapat disikapi oleh generasi muda. Karena generasi muda merupakan cerminan suatu bangsa. Nilai memanusiakan manusia sesuai nilai kemanusiaan yang terdapat dalam pancasila adalah mengenai esensi nilai kemanusiaan yang dapat menjadi upaya bagi generasi muda untuk menyikapi suatu permasalahan kemanusiaan di bangsa ini. Upaya yang dapat dilakukan generasi muda untuk dapat menyikapi persoalan permasalahan adalah dengan menggunakan pemikiran kritis, kesadaran akan lingkungan yang dinamis, dan pengkaitan antara teknologi dalam kajian ilmiah. Hal ini sejalan dengan Triwardani (2013) yang menyatakan bahwa generasi muda harus bisa memanfaatkan pemikiran kritis dengan bantuan teknologi digital yang semakin maju untuk mempersiapkan persoalan nilai kemanusiaan yang ada di lingkungan masyarakat.

\section{Metode}

Dalam penelitian kali ini, menggunakan penelitian kualitatif. Menurut Musianto (2002) penelitian kualitatif melakukan analisis secara data yang bukan berupa angka. Peneliti menilai penelitian kualitatif lebih efektif karena prosedur lebih diperhatikan dibandingkan hasil. Menurut Nazir (1989) mengatakan bahwa pemikiran Lexy J.Moleong banyak manfaat 
yang didapatkan dari penelitian kualitatif karena penelian ini menerapkan kajian secara identifikasi, pedoman dalam penelitian ini merupakan pencarian teori mendasar.pada hasil, dan sifatnya elaborasi.

Salah satu teknik penelitian dalam pendekatan penelitian kualitatif adalah studi literature. Menurut Mulyo (2012) peneliti yang menjadi instrumen utama karena peneliti yang mencari sumber relavan kemudian menganalisis sumber sendiri hingga menjadi satu kesatuan yang sistematis. Menurut Al Habsyi(2017) pengaplikasian studi literature digunakan dengan cara untuk mengumpulkan fakta-fakta yang berkaitan dengan pokok dalam suatu penelitian. Kajian ini, mengambil beberapa pendapat tokoh yang bersangkutan dengan penelitian ini, kemudian dikembangkan lagi sesuai kebutuhan peneliti. Studi literature dilakukan dengan cara membaca, mencatat, dan mengelola bahan penelitian hingga menjadi penelitian yang sistematis dan memiliki nilai guna.

\section{Hasil dan Pembahasan}

\section{A. Nilai Kemanusian dalam Pancasila}

Pancasila yang berarti lima aturan atau larangan sebagai suatu unsur, sendi, dan dasar, memiliki eksistensi yang bernilai kebaikan bagi kehidupan berbangsa dan bernegara. Nilai kemanusiaan yang adil dan beradab seakan menjadi penyaring bagi kehidupan yang berkadilan dan berkeadaban di masyarakat saat ini. Nilai kemanusiaan dengan berbagai perspektif pasti mengkaitkan antara kemanusiaan dengan memanusiakan-manusia lainnya. hidup saling bertoleransi, bekerja secara bersama, menghargai pendapat orang lain, dan mengetahui batasan hak yang dimiliki merupakan cerminan yang ada di dalam sila kemanusiaan.

Nilai-nilai Pancasila juga merupakan suatu pandangan hidup bangsa Indonesia. Pancasila juga merupakan nilai-nilai yang sesuai dengan hati nurani bangsa Indonesia, karena bersumber pada kepribadian bangsa.Nilainilai Pancasila ini menjadi landasan dasar, serta motivasi atas segala perbuatan baik dalam kehidupan sehari-hari dan dalam kenegaraan.Dalam kehidupan kenegaraan, perwujudan nilai Pancasila harus tampak dalam suatu peraturan perundangan yang berlaku di Indonesia.Karena dengan tampaknya Pancasila dalam suatu peraturan dapat menuntun seluruh masyarakat dalam atau luar kampus untuk bersikap sesuai dengan peraturan perundangan yang disesuaikan dengan Pancasila.

Esensi nilai kemanusiaan dalam Pancasila tercermin dari kepribadian bangsa indonesia yang bersifat subjektif karena nilai kemanusiaan merupakan nilai yang melekat di dalam diri bangsa. Hal ini sejalan dengan pendapat Aminnullah (2018) yang menyatakan bahwa pancasila besifat subjektif artinya bahwa nilai-nilai pancasila itu melekat pada pembawa dan pendukung nilai pancasila itu sendiri, yaitu masyarakat, bangsa, dan negara Indonesia.

Indonesia merupakan negara dengan menerapkan sistem demokrasi dan sistem hukum yang sangat ketat dan berkaitan dengan kehidupan bermasyarakatan. Hubungan pancasila dengan perundang-undangan adalah bahwa pancasila merupakan sumber dari segala hukum. Nilai-nilai dalam pancasila salah satunya adalah nilai kemanusiaan, dalam berbagai sumber dijelaskan bahwa nilai kemanusiaan yang adil dan beradab memiliki makna kita sesama manusia mempunyai derajat yang sama di hadapan hukum. Artinya, tidak ada yang diistimewakan dalam kedudukannya sebagai warga negara. Apabila salah satu warga negara melanggar hukum, maka ganjaran atau akbiatnya harus mendapatkan sanksi yang sesuai dengan apa yang diperbuat. Dalam hal ini juga sebagai upaya perlindungan nilai kemanusiaan dengan pendekatan hukum sebagai jalur atau pembatas antara nilai kewajiban dan hak kemanusiaan seseorang. 


\section{B. Fenomena Permasalahan Kemanusiaan di Kalangan Generasi Muda}

Generasi muda merupakan generasi penentu apakah suatu negara dapat dikatakan memiliki kehidupan yang berkeadilan dan berkeadaban di dalamnya, atau tidak adanya kehidupan yang berkeadilan dan berkeadaban. Seperti yang kita rasakan, banyak sekali fenomena yang sangat mengkhawatirkan, karena fenomena tersebut berkaitan dengan moral dan identitas generasi muda sebagai penerus bangsa dengan fenomena permasalahan kemanusiaan yang ada di lingkungan generasi muda. Terjadi degdrasi moral dalam kehidupan bermasyarakat khususnya di kalangan generasi muda sangat bisa dirasakan. Seperti halnya Aristin (2016) mengatakan bahwa media massa baik online maupun elektronik hampir setiap hari menyuguhkan berita yang sangat tidak mencerminkan kepribadian bangsa Indonesia yang berkemanusiaan yang adil dan beradab sesuai sila kedua.

Masalah dan potensi generasi muda yang muncul pada saat ini antara lain adalah menurunya jiwa idealisme, patriotisme, dan nasionalisme di kalangan masyarakat termasuk jiwa pemuda. Selain masalah tersebut, kekurangpastian yang dialami oleh generasi muda terhadap masa depannya juga merupakan masalah yang dapat menimbulkan fenomena kemanusiaan di kalangan generasi muda.

Berbagai permasalahan yang timbul akibat rasa nasionalisme dan kebangsaan yang memudar banyak terjadi belakangan ini, banyak generasi muda atau pemuda yang mengalami disorientasi, dislokasi dan terlibat pada suatu kepentingan yang hanya mementingkan diri pribadi atau sekelompok tertentu dengan mengatasnamakan rakyat sebagai alasan dalam kegiatanya. Sebagai contoh fenomena permasalahan kemanusiaan generasi muda pada saat ini adalah sebuah sikap bodyshaming, yaitu tindakan yang dilakukan sesorang yang dapat menyakiti perasaan orang lain, hal ini dilakukan bisa secara fisik dan verbal. Dalam fenomena tersebut, bisa dilihat krisis moral yang terjadi di kalangan generasi muda yang seakan-akan sebuah ledekan merupakan suatu kebiasaan yang dibiasakan timbul serta yang lebih parah diwajarkan ada di masyarakat. Hal ini tentu bukan sebagai cerminan dari nilai kemanusian yang adil dan beradab.

Permasalahan lain yang tidak kalah penting adalah menyebarkan ujaran kebencian kepada seseorang melalui media massa berupa social media. Kemudahan akses internet menjadi penyebab seseorang dapat dengan mudah mengetahui informasi dan memberikan argumen. Jika hal tesebut tidak difilterisasi dengan nilai pancasila sila kedua yaitu kemanusiaan, maka akibatnya akan banyak generasi muda yang bebas memberikan tanggapan berupa ujaran kepada seseorang.

\section{Nilai Kemanusiaan yang Harus diperhatikan dalam Kehidupan Bermasyarakat}

Sejatinya hidup dalam sebuah tempat atau wadah yang dinamakan lingkungan. Dalam hal ini kehidupan selalu mengikuti arah kemana lingkungan ini berada. Hal ini sejalan dengan pendapat Monalisa (2016) sikap peduli terhadap lingkungan merupakan reaksi alamiah seseorang. Untuk bisa dihargai di lingkungan masyarakat dengan baik, maka kita juga harus menghargai dan menghormati hak asasi dari setiap orang. Kendati demikian, lalu bagaimana yang seharusnya dilakukan seseorang dalam kehidupan bermasyarakatan, jawabannya adalah dengan memiliki rasa Nilai kemanusiaan. yang harus diperhatikan dalam kehidupan bermasyarakat adalah hak dan kewajiban masyarakat. Menurut Yasin (2009) hak dan kewajiban sesorang memiliki batasan-batasan yang harus dipahami. Artinya setiap orang memiliki hak untuk melakukan sesuatu namun disampin itu juga memiliki kewajiban dalam kehidupan bermasyarakat. Selanjutnya adalah Perlakuan yang adil terhadap sesama manusia, terhadap diri sendiri, alam sekitar dan Tuhan. Sebagai masyarakat kita harus berlaku adil kepada diri sendiri dan orang disekitar kita demi kelangsungan kehidupan bermasyarakat. Selain perlakuan adil, selanjutnya adalah manusia sebagai makhluk beradab atau berbudaya yang memiliki daya, cipta, rasa, karsa, dan keyakinan. Dalam hal ini sikap saling menghargai diperlukan untuk kehidupan yang 


\section{Jurnal Evaluasi dan Pembelajaran, 3 (1), Maret 2021 - 41}

Awalia Marwah Suhandi, Dinie Angraeni Dewi

berjalan dengan rukun. Dalam menghargai dan menghormat orang lain maka dibutuhkan nilai pancasila untuk menjadi kekuatan diri dalam kehidupan bermasyarakat. Hal ini sejalan dengan pendapat Muhammad Mona (2020) nilai pancasila memiliki peran utama dalam membangun dan meningkatkan kepribadian yang baik di kehidupan bermasyarakat.

Nilai kemanusiaan yang adil mengandung suatu makna bahwa hakekat manusia sebagai makhluk yang berbudaya dan beradab harus berkodrat adil. Hal ini mengandung suatu pengertian bahwa hakikat manusia harus adil dalam hubungan dengan diri sendiri, adil terhadap manusia lain, adil terhadap masyarakat, bangsa, negara, dan adil terhadap lingkungannya serta adil terhadap Tuhan Yang Maha Esa.

Kemanusiaan merupakan wujud dan kehadiran dari reaksi-reaksi antar masyarakat yang memandang satu sama lain sebagai sesamanya yang layak dan harus dihormati. Kemanusiaan merupakan wujud tertinggi dari kehidupan yang berdasarkan atas saling menghargai dan menghormati. "Kemanusiaan" adalah perkara pembelaan dan pengedepanan bentuk-bentuk pemuliaan manusia seperti apa adanya. Seorang penari tradisional yang gerak-geriknya tampak terlihat beda dengan asumsi kesopanan kita, misalnya, tidak serta merta melawan atau bertentangan dengan prinsip kemanusiaan. Sebab, tubuh manusia dengan segala gerakannya kerap mengatakan simbol-simbol rohani yang kontekstual.

\section{Esensi Nilai Humanisme Pancasila}

Menurut Hardiman (2012) nilai humanisme dalam nilai pancasila seakan-akan menjadi dua sisis yang berbeda ketika dimaknai di masyarakat. Dalam hal ini, nilai humanisme oleh beberapa pihak dijadikan pengantar nilai kesejatian dan kerukunan untuk kehidupan berbangsa. Namun adapula yang menjadikan nilai humanisme sebagai kata biasa dan tidak memaknai esensi nilai humanisme atau nilai kemanusiaan yang ada di masyarakat. Nilai kemanusiaan dalam Pancasila dapat dilihat dari susunan sila-silanya sebagai satu kesatuan. Bahwa kemudian ada satu prinsip yang secara khusus berbicara mengenai itu menunjukkan bahwa para pendiri bangsa melihat nilai kemanusiaan sebagai konsep yang hidup dalam masyarakat Indonesia.

Nilai pancasila lahir dari bangsa Indonesia sendiri. Dengan kata lain ia merupakan produk budaya yang telah meresap dan mengakar dalam jiwa dan raga masyarakat Indonesia sejak dulu. Pancasila sebagai local genius atau yang bisa disebut pemikiran khas Indonesia memiliki pengertian yang spesifiknya adalah menganai identitas budaya Indonesia. Penyebutan identitas budaya lebih menunjuk kepada nilai-nilai kebudayaan yang terus hidup dan berkembang di tengah masyarakat Indonesia, alih-alih sebagai nilai-nilai warisan masa lalu yang sudah usang. Dengan demikian Pancasila bukan milik negara melainkan milik masyarakat demi keadaban kehidupan bangsa.

Nilai-nilai kemanusiaan memiliki akarnya yang jauh di dalam budaya masyarakat Indonesia, bahkan juga terefleksikan dalam kehidupan keagamaan mereka. Jika dalam sila pertama disebutkan Ketuhanan Yang Mahaesa, maka konsekuensinya bukan semata-mata urusan ritual dengan Sang Pencipta melainkan juga terkait dalam hubungan dengan sesama manusia.

Di dalam sila itu secara implisit terkandung nilai penghargaan terhadap agama dan kepercayaan masing-masing, kesediaan menghormati dan bekerja sama dengan pemeluk agama dan penganut kepercayaan yang berbeda-beda sehingga terbina kerukunan hidup, saling menghormati kebebasan menjalankan ibadah sesuai dengan agama dan kepercayaannya, dan tidak memaksakan suatu agama dan kepercayaan kepada orang lain. Pancasila merupakan pandangan hidup bangsa Indonesia. Karena Pancasila merupakan cerminanan kepribadian bangsa indonesia. Walaupun pada mulanya ia adalah konsensus politik yang dibuat untuk mengatasi atau menjembatani berbagai perbedaan dan kepentingan di kalangan masyarakat, pada hasil akhirnya Pancasila menjadi pedoman 
dalam hidup bermasyarakat, berbangsa, dan bernegara. Hal ini tidak lain karena Pancasila digali dari akar budaya bangsa Indonesia sendiri yang kental dengan nilai-nilai kemanusiaan, nilai-nilai mana mewarnai seluruh sila di dalam Pancasila itu sendiri.

\section{E. Gambaran atau Skema Solusi Esensi nilai Humanisme di Generasi Muda}

Fenomena kemanusiaan yang hadir pada zaman sekarang ini tidak luput dari kemajuan peradaban pada saat ini. Globalisasi sebagai bumerang bagi bangsa indonesia apakah dapat disikapi sebagai tantangan atau hambatan bagi bangsa Indonesia khususnya generasi muda. Kemajuan globalisasi menyebabkan adanya kemajuan teknologi, teknologi dapat menjadi tantangan apabila kita dapat mengambil ilmu pengetahuan baru dan memanfaatkannya untuk kehidupan bernegara. Namun, apabila teknologi tersebut disalahgunakan khususnya oleh generasi muda, bukan tidak mungkin pasti teknologi tersebut digunakan untuk hal-hal yang sifatnya buruk seperti melakukan Hate Comment.

Dalam upaya penanganan krisis moral nilai humanisme tersebut nilai pancasila hadir sebagai upaya penanganannya. Karena nilai pancasila merupakan nilai yang sifatnya berupa cerminan luhur kepribadian bangsa. Nilai yang terkandung dalam Pancasila harus digunakan oleh semua kalangan khususnya kalangan generasi muda untuk membentengi diri oleh upaya modernisasi dan globalisasi yang ada pada saat ini. Ketika generasi muda telah mengamalkan dan menjiwai nilai-nilai pancasila di dalam dirinya, maka generasi muda akan mengambil semua nilai kebaikan berupa toleransi dan saling menghargai satu sama lainnya. ketika generasi muda sudah mengetahui pentingnya toleransi dan menghargai pendapat seseorang maka akan terciptanya suatu kehidupan yang dicita-citakan bangsa Indonesia. Yaitu, hidup rukun dan mencinta bangsa dan tanah air.

\section{Simpulan}

Generasi muda merupakan tolak ukur kemajuan suatu bangsa dengan menjiwai dan mengamalkan nilai pancasila khususnya nilai kemanusiaan maka akan menghantarkan kepada sebuah jalan menuju puncak kebahagiaan kehidpuan di dunia yaitu sikap menghargai dan toleransi di dalam kehidupan bermasyarakat.

\section{Daftar Pustaka}

Aminullah. (2018). Implementasi Nilai-Nilai Pancasila dalam Kehidupan Bermasyarakat. Jurnal ilmiah IKIP Mataram. Vol 3. 620-628.

Arif, S. (2016). Falsafah Kebudayaan Pancasila. Jakarta PT Gramedia Pustaka

Aristin, R. (2016). Aktualisasi Sila Kemanusiaan yang Adil dan Beradab Di Era Reformasi. Aspirasi : Jurnal ilmiah Administrasi Negara. Vol 1, hal 4.

Airlam, L. (2018). Perlindungan Hukum Bagi Anak Dalam Perspektif Pancasila dan Bela Negara. Unifikasi : jurnal ilmu hukum. Vol 5, 58-70.

Evie, S. (2014). Pengintegrasian Nilai-Nilai Kemanusiaan (Human Values) Dalam Pembelajaran Tematik Sekolah Dasar. Jurnal Kreatif Tadalako. Vol 2. Hal 54.

Habsy, A. (2017). Seni Memahami Penelitian Kualitatif Dalam Bimbingan Konseling :Studi Literature. Jurkam : Jurnal Konseling Andi Matappa, 01. 90-100 


\section{Jurnal Evaluasi dan Pembelajaran, 3 (1), Maret 2021 - 43}

Awalia Marwah Suhandi, Dinie Angraeni Dewi

Hardiman, B. (2012). Humanisme dan Sesudahnya. Jakarta : KPG (kepustakaan populer gramedia)

Rianto, H. (2016). Implementasi Nilai Kemanusiaan yang Adil dan Beradab di Lingkungan Sekolah. Jurnal pendidikan sosial. Vol 3, 80-91.

Mulyo, Rahardjo (2012). Model Pembelajaran Inovatif. Yogyakarta : Gava Media

Musianto (2002). Perbedaan Pendekatan Kuantitatif dengan Pendekatan Kualitatif dalam Metode Penelitian. Puslit Petra : Jurnal Manajemen dan Kewirausahaan, 04.123-136

Mustohfa. (2017). Pendidikan Islam Perspektif Humanisme-Pancasila. Jurnal Tarbiyah. Vol 24. Hal 157.

Monalisa, R. (2016). Peranan Lingkungan Sosial Terhadap Pembentukan Sikap Peduli Lingkungan Peserta Didik Di SMA Negeri Kabupaten Cinajur. Jurnal Pendidikan Geografi. 16, 44-55.

Mona, M. (2020). Kekuatan Nilai Nilai Pancasila dalam Membangun Kepribadian Masyarakat Indonesia. Jurnal Al-Adabiya. 15, 121-138.

Nazir, Moh. (1988) Metode Penelitian. Jakarta: Ghalia Indonesia

Triwardani, Y. (2013). Memanusiakan manusia dalam lingkungan yang tangguh. Jurnal Antropologi Indonesia. Vol 1, 78-89.

Yasin, J. (2009). Hak Azasi Manusia dan Hak serta Kewajiban Warga Negaa dalam Hukum Positif Indonesia. Jurnal Artikel Ilmu Pengetahuan sosial. 1-17. 